\title{
Searching for Selfhood: Ricoeur's Recognition and Cavellian Acknowledgment
}

\author{
Klementyna Chrzanowska \\ (Jagiellonian University in Cracow, cklementyna@gazeta.pl)
}

\section{Introduction}

It is often presumed that, where the subject of the subject or the self is concerned, the height of Ricoeur's philosophical achievement is to be found in Oneself as Another. This expansive volume proceeds in an orderly fashion to paint an ever-growing portrait of human capabilities, with the famous theory of narrative identity at its very literal center. Yet, if we focus too much on the authoring of oneself that is the essence of the narrative theory, we are in danger of ignoring what Ricoeur calls "the dimension of lack, the fact that we need friends" (Ricoeur 1995, p. 192) in other words, the need for recognition/acknowledgment that becomes the focus of one of his last books, Parcours de la Reconnaissance, or The Course of Recognition. This paper aims to outline how the findings of that work fit into Ricoeur's philosophy of selfhood, and to do so by comparing Ricoeur's analyses of the concept of recognition and Stanley Cavell's explorations of the idea of acknowledgment.

First, I will briefly outline the reasons for juxtaposing these two philosophers, and point out the sources of their interest in the idea of recognition and its place in their respective philosophies. Then, the concepts of recognition and acknowledgment will be properly compared and Ricoeur's theory of recognition examined so as to point out the ways in which Cavell's philosophical findings can complement it. This will inevitably lead us to the idea of risk and the idea of vulnerable others, which still beg further research.

\section{Ricoeur and Cavell}

Why, then should Cavell and Ricoeur be thrown together? The vast difference in styles and backgrounds between these two philosophers has perhaps hindered attempts at a fruitful reading-together of their texts, despite the vast similarity of views that can also be found between them. They both think of selfhood in terms of becoming, they both inscribe it within an ethical horizon, and they both see it as opaque and fragile. In both their philosophies the selfprogresses from self-designation to responsiveness and responsibility. But most importantly, the concept in focus here, that of recognition/acknowledgment, is part of a larger epistemological paradigm they share. For both Cavell and Ricoeur, there are no absolute certainties in 
their thinking about identity and selfhood - there is attestation, testimony, the giving of proof - something that can be recognized and acknowledged, or denied. And so there is a need for a witness. Thus it is their shared paradigm of trust, rather than of certainty, that is the impulse behind the comparison.

But how does each of them arrive at the need to theorize about recognition/acknowledgment? Ricoeur admits outright that his impulse to delve into the subject arose from the observation that the concept of recognition, despite its semantic richness, lacks its own theory, the way that the concept of knowledge does not (Ricoeur 2007, ix). But that alternative epistemological paradigm of which recognition is part can already be found throughout Oneself as Another, with its repeated appeals to attestation. The self cannot be posited as certain: if one definite criterion of selfhood is searched for, the search is sure to fail. As Nietzsche or Parfit show, if what we want is certainty, then we are doomed to failure. At best, we can posit the "I" as a linguistic illusion, as Anscombe does. It is to escape this unhappy consequence that Ricoeur tries to place his hermeneutics of the self "at an equal distance from the apology of the cogito (understood in the Cartesian sense) and from its overthrow" (Ricoeur 1995, p. 4). When it comes to selfhood, we cannot have the kind of knowledge that would serve as absolute recourse against all doubt. We can only have the kind of knowledge that is recognition.

Cavell arrives at the very same conclusion, but from the opposite direction. His point of departure is not the philosophy of selfhood, but his attempts to understand skepticism as both a human propensity and a serious challenge to philosophy. According to Cavell, what began rather innocently with Descartes' Meditations turned, during the Enlightenment, into not only "a Faustian desire to know everything, but a demonic will to measure every relation against that of knowing" (Cavell 2002, xxvii). Thus in his seminal The Claim of Reason Cavell analyzes skepticism concerning knowledge, skepticism concerning the very possibility of communication, and the skeptical problem of other minds. Transferred onto a philosophy of selfhood, all of these make for a very weak, uncertain subject. But the moral of Cavell's philosophy of self is that we must reject such pretensions to certainty and rely on acknowledgment instead.

\section{Recognition and Acknowledgment}

But let us turn to specifics: how is the concept of recognition to be understood, in what ways does it overlap with acknowledgment, and what exactly is the relation of these concepts to that of knowledge. Since Ricoeur's starting point is a thorough lexicographical investigation of the ordinary language uses of the verb "to recognize" based on the Littré and Grand Robert dictionaries, I have done the same for the verb "to acknowledge" based on Collins and American 
Heritage dictionaries. For our purposes, the major senses of the two verbs are as follows:

\section{To Recognize:}

- To grasp (an object) with the mind, to distinguish or identify;

- $\quad$ To accept, take to be true, admit, avow (Ricoeur 2007, p. 12);

- particularly, "to admit as true after having denied, or after having doubted, to accept despite some reservations" (Ricoeur 2007, p. 15)

- To bear witness through gratitude that one is indebted to someone for smth.

\section{To Acknowledge:}

to admit the existence or truth of smth to indicate or express recognition of to express gratitude or appreciation or thanks for to report the receipt of smth to the sender/giver

Table 1. Comparison of the terms "to recognize" and "to acknowledge."

Several important points need to be made here. Firstly, the three above mentioned senses of recognition signal already the themes taken up by Ricoeur in his three successive chapters. The first one, "Recognition as Identification" explores that first meaning, connected with the work of the mind trying to capture sense. The second meaning signals the overlap of recognition and attestation/avowal explored in the second chapter, "Recognizing Oneself," and finally, the third meaning signals the involvement of the other, dealt with in the chapter on "Mutual Recognition."

Secondly and most importantly, the first meaning of "to recognize" is the one most closely connected with logical identification of objects, and therefore closely overlaps with knowledge, with the acquisition of knowledge. To recognize an object or a person in this sense is to identify, to gain knowledge about the world. This contrasts with all the other meanings listed of both "recognize" and "acknowledge," 1 which refer not to the acquisition of knowledge, but to something being done in the face of that knowledge; not to a solely mental act ("grasping with the mind"), but to an expressive speech act. This idea of expression is at the heart of the (ever so slight) difference between Ricoeur's and Cavell's conceptions: where Ricoeur focuses on the shift from recognition as knowledge to recognition per se, Cavell will focus on the gap between knowledge and the act of acknowledging that knowledge. ${ }^{2}$ Looking at those definitions of "to acknowledge," we see clearly the sense of

1 Meanings 2 and 3 of "to recognize" clearly overlapping with meanings $1-3$ of "to acknowledge".

2 To use the simplest of examples, walking on the street I may recognize someone I know, but being angry at them, I might not want to acknowledge that recognition with a nod, what's worse, I may even hide. 
Cavell's words: "Acknowledgment goes beyond knowledge. (Goes beyond not, so to speak, in the order of knowledge, but in its requirement that I do something or reveal something on the basis of that knowledge)" (Cavell 2002, p. 257).

Naturally, Ricoeur moves from the lexical groupings of the meanings of recognition to a working out of its philosophical significance. His main hypothesis is that the philosophical meanings of the verb to recognize can be found "along a trajectory running through its use in the active voice to its use in the passive voice" (Ricoeur 2007, p. 19). This path from "I recognize" to "I am recognized" forms the backbone of the course of the three chapters ("Recognition as Identification," "Recognizing Oneself," and "Mutual Recognition"). On the active end, recognition overlaps with knowledge, but, as an act, it "expresses a pretension, a claim, to exercise an intellectual mastery over this field of meanings, of signifying assertions" (Ricoeur 2007, p. 19). And rather than a state, it is an activity, a change of state achieved through the work of the mind. ${ }^{3}$ On the passive end, the "fact that we need friends" comes into play; "I am recognized" becomes a request where that very recognition is at stake: "the demand for recognition expresses an expectation that can be satisfied only by mutual recognition" (Ricoeur 2007, p. 19). In that reversal we also see a gradual detaching of the concept of recognition from that of knowledge. Ricoeur writes that at the final stage, it is recognition that opens the way toward knowledge (Ricoeur 2007, p. 22). How are we to understand this? We need to keep in mind that what is being recognized here is actually selfhood: "it is our most authentic identity, the one that makes us who we are, that demands to be recognized" (Ricoeur 2007, p. 22). In this sense, being recognized as a person, as a fellow (rational) human being, is a precondition of being known, and recognizing the other is the precondition of knowing the other.

It is now becoming clear that Ricoeur's analyses of the various stages of recognition are more than an elucidation of that philosophical concept. Brought together, the three chapters on recognition can be read as an "existential elucidation" of selfhood, a philosophy of a developing self that is broad in scope, where the narrative self is inscribed into a dialogue that arises together with the demand to be recognized.

Before we go on to analyze what I claim to be Ricoeur's theory of recognition-as-self-constitution, let us come back to Cavellian acknowledgment and see what it can bring into focus. As we have already said, acknowledgment is something done with knowledge, and it is always expressed, intersubjective, in public space. Thus even if self-knowledge or selfrecognition is our subject, the idea of acknowledgment highlights the need for an audience: it is to someone else that I must acknowledge how things are

${ }^{3}$ When it comes to Cavellian understanding of self-knowledge, it runs along the same lines. But his concept of acknowledgment has a narrower meaning. 
with me. Lack of this public acknowledgment can lead to self-deception and solipsism. But to acknowledge publicly how things are with me is also to present myself for acknowledgement. Cavell writes of the need for mutual acknowledgement just as much as Ricoeur writes of the need for mutual recognition, but he is more thorough in analyzing the risks that are involved. For what is the opposite of acknowledgement? It is not ignorance, but avoidance, and consequently denial, annihilation even. If I am not recognized, I may disappear. If I fail to acknowledge my other, I am making him disappear. And crucially, this annihilation is a commonplace occurrence, part of our everyday interactions. It may happen "in as small a thing as my slighting an expectation, or withholding praise, or perhaps out of the human failing of ingratitude" (Cavell 2006, p. 5).

But keeping in mind Cavell's skeptical background, acknowledgment is less what is done with knowledge, and more what is done in face of the limitedness of our knowledge, of the necessary lack of certitude. Acknowledgement is a way of coming to terms with one's practical finitude: it is trusting and, importantly, actively agreeing that what little knowledge we have of the other must be enough. ${ }^{4}$

\section{Towards a Theory of Recognition}

How can this help us read The Course of Recognition? First of all, Ricoeur himself leaves us with an interpretation of the book in its very conclusion, pointing out those "underlying problematical issues whose organizing power really appears only on rereading" (Ricoeur 2007, p. 249). And even though he himself is far from admitting that he has formulated a coherent theory, it could be claimed that he has outlined such a theory, at the very least. And further, that theory is full of themes dear to Stanley Cavell, so that reading them together can help fill in the gaps.

Ricoeur's key to reading The Course of Recognition is simple: throughout the three chapters, a progression of three themes should be observed: "the theme of identity, then, passing beyond it, that of otherness, and finally, in a more hidden background, that of the dialectic between recognition and misrecognition. This last theme especially receives more treatment in the conclusion than it does anywhere else in the book. In the end, Ricoeur picks it out as noteworthy, despite the fact he has not given it a thorough treatment himself. Let us help ourselves with a table to better understand the course and traps of recognition:

\footnotetext{
4 The Wittgensteinian conception of language, with public, agreed upon criteria, comes into play very strongly in Cavell's philosophy: it is only thanks to our agreement that words can mean, and so they are fragile, and so they are our responsibility.
} 


\begin{tabular}{|c|c|c|c|}
\hline CHAPTERS $\rightarrow$ & $\begin{array}{l}\text { Recognition as } \\
\text { Identification }\end{array}$ & $\begin{array}{c}\text { Recognizing } \\
\text { Oneself } \\
\text { (Attestation, Self- } \\
\text { Assertion) }\end{array}$ & $\begin{array}{l}\text { Recognition of/by } \\
\text { the Other (Mutual } \\
\text { Recognition) }\end{array}$ \\
\hline Identity & $\begin{array}{l}\text { something, } \\
\text { someone (in } \\
\text { general) }\end{array}$ & $\begin{array}{l}\text { oneself: } \\
\text { narrative identity } \\
\text { attesting to one's } \\
\text { capacities, } \\
\text { promise, memory }\end{array}$ & $\begin{array}{l}\text { each other / one } \\
\text { another } \\
\text { others' recognize } \\
\text { one's range of } \\
\text { capacities }\end{array}$ \\
\hline Otherness & $\begin{array}{l}\text { expectation of the } \\
\text { approbation of } \\
\text { others }\end{array}$ & $\begin{array}{l}\text { public, calls for an } \\
\text { ear, expectation of } \\
\text { being heard; } \\
\text { action involves } \\
\text { interaction }\end{array}$ & $\begin{array}{c}\text { innumerable figures } \\
\text { of Alterity, } \\
\text { non-commercial } \\
\text { reciprocity, love, } \\
\text { law, social esteem }\end{array}$ \\
\hline $\begin{array}{l}\text { Recognition vs } \\
\text { Misrecognition }\end{array}$ & fear of mistakes & $\begin{array}{l}\text { incapacities and } \\
\text { self-deception, } \\
\text { mistaking oneself }\end{array}$ & $\begin{array}{l}\text { a struggle against } \\
\text { misrecognition; } \\
\text { contempt }\end{array}$ \\
\hline
\end{tabular}

Table 2. Themes of recognition Ricoeurian organized by chapter.

Whereas Ricoeur discusses the successive rows of this table in his concluding remarks (2007, pp. 249-263), let us, for simplicity's sake, discuss the columns. At the level of identity, Recognition as Identification is just that, the ability to grasp an object with the mind, to identify or to re-identify it as that very thing, to define it, asserting its identity. The intersubjective dimension of otherness comes in with language - even if at this level it is only the language of declarative sentences. Identification as a speech act presupposes an audience: "Taken as an act of language, the assertion invested in the act of judgment requires the commitment of the speaker just as much as do other specific performative locutions, for which the promise remains a key example. And this commitment includes an expectation of the approbation of others" (Ricoeur 2007, p. 255). However solitary the thinker, in language he is always before others. Ricoeur gives the example of Descartes, who published his seemingly solitary and solipsistic Meditations in one volume with the "Objections and Replies." Descartes continues to be a good example when Recognition/Identification is considered at the level of the threat of misrecognition. The very aim of the Meditations is, after all, to find knowledge that is certain and not prone to mistakes, to "ward off the possibility of error" completely. That this cannot be, that Descartes' "demonic" drive towards certainty costs him the world and shows him to be ever so slightly mad, is a point driven home by Cavell. One of the aims of his The Claim of Reason is to show that the threat of skepticism is ever-present through the very way in which we possess language. Misunderstanding, Ricoeur will point out, is a 
realization of that threat in that it "shakes our confidence in the capacity of things and persons to make themselves recognized" (Ricoeur 2007, p. 256). Cavell will point out that in such a case suspicion can be aimed two ways: at the one making oneself recognized, and at the one doing the recognizing: "Am I distrusting you (your capacity as a knower of others) or myself (my capacity to give myself expression)?" (Cavell 1999, p. 382). This kind of doubt can silence one completely; at the very least, it can illuminate the often dramatic character of attempts to speak. Yet this kind of doubt is something we have to learn to live with; that is both Cavell's and Ricoeur's conclusion. The latter recommends: "An acceptance of a kind of companionship with misunderstanding, which goes with the ambiguities of an incomplete, openended life world, has to replace the fear of error" (Ricoeur 2007, pp. 256-257).

Moving on to the chapter on Recognizing Oneself, the level of identity is the level of reflexivity directed toward the self. Assertion is now self-assertion, and it consists in the attesting of the self's human capacities: the power to speak, to act, to narrate, to promise, to remember, and to recognize oneself as morally responsible for one's actions. But attesting happens in the very exercise of those modalities of the "I can," and that exercise invariably implies the presence of otherness. The level of identity is thus the level of potential actions: as soon as actual speaking, acting, or narrating, the level of otherness intrudes, and the bonds of intersubjectivity cannot be abstracted from (Ricoeur 2007, p. 253). Speaking and narrating call "for an ear, a power to hear, a reception." Acting involves interacting with others. Narratives weave together intersecting life stories. Imputability implies an accuser, or a judge. Capacities connected with promises and memory reveal recognition as something happening in time and before others. Self-assertion is thus not solipsistic, but public. As an example, Ricoeur recalls Homeric heroes: "The whole Greek army gathered before its ships bears witness to the exploits of its leaders. Achilles' anger is public; his withdrawing into his tent takes place before everyone" (2007, p. 252). However, Ricoeur is quick to point out that while intersubjectivity is a necessary condition of self-assertion, it is not its basis: that basis is the power to act.

Yet the story of self-attestation does not end with its robust, public expression. It must still face the test, or the threat, of misrecognition. ${ }^{5}$ The possibility of self-deception, or simply of mis-taking oneself, of lacking selfknowledge, spills over onto others, creating the possibility of us being mistaken about them, and about our relations with them. Each capacity has an incapacity connected with it, and Ricoeur draws our attention particularly to the difficulty of putting things into words, as well as the difficulty of discerning

${ }^{5}$ It needs to be mentioned that the themes Ricoeur points out in this section require further development and elucidation. The topic of incapacities, for example, is barely signaled by the author. For Cavell, on the other hand, the difficulty and cost of speaking is one of his central themes. 
our motivations for speaking: "The kinship among secret, inhibition, resistance, disguise, lie, and hypocrisy is as close as it is hidden" (Ricoeur 2007 , p. 257). What is more, the power to perjure oneself throws a shadow over the ability to promise, and over the institution of language as a whole "insofar as it depends on our confidence in what others say" (Ricoeur 2007, p. 258). Ricoeur even calls this capacity for betrayal "frightening," since it is an active power involving choice, as opposed to passive forgetting - yet another face of misrecognition.

Finally, there's the chapter on Mutual Recognition, where the interplay between the I and the other takes full force, and where 'recognition' and 'acknowledgement' become almost interchangeable. At the idealized level of identity, we receive the full assurance of our identities from one another, through the recognition of the full range of our capacities (Ricoeur 2007, p. 250). It is part of our human nature that our identities are not complete without this kind of recognition. But it is at the level of otherness that the reality of the "innumerable figures of alterity" really impinges on us. Here recognition is not a given, but it is something that must be struggled for, making confrontation our central concern. That confrontation, however, reveals many different faces within Ricoeur's analyses: it takes the form of conflict, compromise, and, in the exchange of gifts, a shared generosity. ${ }^{6}$ Most importantly, mutuality is the key concept here: on a personal level, friendship is the mutual approval of each other's existence - I am because you love me; you are because I love you; on a juridicial level, we recognize that all people are equal before the law. "Deprived of approbation, the person is as if nonexistent," writes Ricoeur in a very Cavellian tone (2007, p. 191).

But it needs to be pointed out that there is a double bond hidden here, which requires further exploration. I (passively) need your recognition to exist, but I (actively) need to recognize you, not just for your sake, but for my own, for the sake of my own existence as a human being. My very capacity for the recognition of another is something that must be attested to. "Being human is the power to grant being human," writes Cavell (1999, p. 397). Being human is to acknowledge that yes, you are human, too. My relationship to you, its acknowledgment or denial, is part of my identity. Thus Ricoeur writes of "the profound unity of self-attestation and of the injunction coming from the other" (Ricoeur 1995, p. 355). And sums up mutual recognition as "a struggle against the misrecognition of others at the same time that it is a struggle for recognition of oneself by others" (2007, p. 258).

${ }^{6}$ Due to the many possible levels of interpersonal experience (personal, social, legal), this paricular square in our table is connected with a plethora of theories. Ricoeur himself bears witness to this richness, analyzing a range of approaches, from Hegel and Honneth to Charles Taylor, through Boltanski and Thévenot's economies of standing. 
Here, at the very end, when recognition has run its course, the threat of misrecognition on the plane of mutual recognition is given the symbolic name of contempt. Contempt (mépris) is the result, on the interpersonal plane, of making a mistake (méprise), mistaking oneself and others for something they are not. It is emblematic of all those negative feelings connected with denial and conflict (Ricoeur 2007, p. 258). Again, it can be both the contempt I feel for others, and the contempt I experience from them: both are a threat to my selfhood. And yet, as Ricoeur points out, they are an essential part of the dynamic of winning recognition, just as mistakes are part and parcel of the search for truth. Crucially, this inherence of misrecognition in recognition has already been signaled at the level of the survey of meanings of 'to recognize': the second meaning included the meaning of 'to admit', particularly, "to admit as true after having denied, or after having doubted, to accept despite some reservations" (Ricoeur 2007, p. 15). Here recognition is the overcoming of doubt, not once, but again and again. ${ }^{7}$ This meaning, connected with seeing the limitedness of our knowledge, is of course also the basic meaning of Cavellian acknowledgment, with its requirement of expression.

\section{The Threat of Misrecognition: Cavellian Examples}

Thus, attempts to overcome the double threat presented by misrecognition reveal themselves as a crucial step in the constitution of selfhood, or preservation of personal identity. This finding of late Ricoeurian thought can be fleshed out and brought to life through examples taken from Cavell's philosophy, which so boldly develops the theme of risk connected with revealing the self. Let us take a look.

The act of narrating one's story is a form of recognizing/acknowledging how things are with me, a way of giving testimony about oneself, attesting one's identity, a form of avowal. ${ }^{8}$ As such, it requires a response; it is part of a dialogical relation: the witness attests before someone, and asks to be believed. In the judicial context, "the certifying of testimony is not complete until it is not only received, but accepted and eventually recorded" (Ricoeur 2007, p. 131). Cavell calls this presenting oneself for acknowledgment (Cavell 1999, p. 393; Cavell stresses that to do this, to believe I have the capacity to do this, requires 'believing myself' - something already susceptible to sceptical doubt). However I have weaved my tale, it cannot remain just a monologue: at the very least, I need a nod of recognition. And, as Ricoeur notes, "in the test of confronting others, narrative identity reveals its

7 Ricoeur acknowledges this "always incomplete nature of the struggle for recognition" (2007, p. 259).

${ }^{8}$ Ricoeur gives the example of Augustine's Confessions as a paradigm of 'a discourse of avowal' (2007, p. 118), and of course an entire genre of 'confessional literature' has sprung up since. 
fragility" (Ricoeur 2007, p. 104). The stakes, after all, are enormous, and they get bigger the closer my relationship is to the one from whom I seek acknowledgment. Cavell writes thus about the best case of acknowledgment, the case of the one I love:

No one else is in my position with respect to this other. I and this other have been singled out for one another. This is what a best case comes to. If it fails, the remainder of the world and of my capacities in it have become irrelevant. That there are others, and others perhaps in my position in relation to them, are matters not beyond my knowledge but past my caring. I am not removed from the world; it is dead for me. All for me is but toys; there is for me no new tomorrow; my chaos is come (again?). I shut my eyes to others (Ricoeur 2007, p. 430).

This, indeed, is tragedy. That is why Cavell reaches back to his essays on Shakespeare in the last part of The Claim of Reason, the part entitled 'Skepticism and the Problem of Others.' After all, "acknowledgment is to be studied, is what is studied, in the avoidances that tragedy studies" (Ricoeur 2007, p. 389).

So what are the possibilities, what are the exact risks we run in presenting ourselves for acknowledgment? First and foremost, I, my testimony, may be rejected, as in the quote above. Others may attempt to impose their own narratives onto me, trying to make me into something I am not. I may be denied to the point of death: Cordelia is declared by Lear to no longer be his daughter, she is banished by him from the land, and as a consequence of his denial in the end she suffers death. Hermione's testimony of having been a true and faithful wife is rejected by her husband Leontes in the fable-like The Winter's Tale, and as a consequence, she is turned to stone. Many years later, when her husband sees the error of his ways, admits his mistake, and acknowledges the truth of her, resurrection is possible for Hermione. Not so for Desdemona: her skin may be "smooth, as monumental alabaster" (V, ii, 5), but she is irreversibly dead. Dead not because of Othello lack of knowledge, but because of his lack of acknowledgment: "He knew everything, but he could not yield to what he knew, be commanded by it" (Ricoeur 2007, p. 496).

In the above examples, death is not the price paid willingly; it is not a consequence that has been foreseen. Yet the human drive to acknowledgement is so strong that sometimes death is an acceptable price for recognition. ${ }^{9}$ Such are the scenarios imagined by Edgar Allan Poe in his confessional tales, analyzed by Cavell in his essay Being Odd, Getting Even (see: Cavell 1994, pp. 105-149). The story entitled The Imp of the Perverse is a particularly striking example: here the narrator is writing from jail something that is meant to be

${ }_{9}^{9}$ Antigone is of course another example quoted by Cavell where "the cost of claiming one's identity may claim one's life" $(1999,389)$. 
an explanation for his actions. The narrator worries that without such an explanation (he has killed a man who was kind to him, for no reason at all), the reader might "have misunderstood me altogether" or else "fancied me mad," failing to see the narrator as "one of the many uncounted victims of the Imp of the Perverse." And he wants to count, to be counted, to be recognized, to be part of the society of intelligible beings - even if that counting consists in being brought to account and being punished. His death sentence is the result of his participation in the justice system, and that participation means he counts as human, as accountable, and not as mad. Cavell argues that the confession costs him his life, but safeguards his identity: something "more original, even humanly more needful" (Cavell 1994, p. 143).

Lastly, and perhaps most commonly, the confrontation with others might reveal the very fragility of my narrative. I may be proven wrong. It may be pointed out to me that I was mistaken in my narrative of myself and of my relations with others, or that I have wittingly or unwittingly lied to myself. The question is, how will I take it? When Cordelia disrupts Lear's narrative by refusing to participate in the bidding war for his love, he does not take it well. On Cavell's reading, it is shame that is the driving force behind Lear's violent reaction and rejection of Cordelia: her reaction makes him realize the absurdity, the shamefulness of his request, but he is completely unwilling to admit it. Instead of acknowledging his mistake, his anger falls upon Cordelia (see: Cavell 2002, p. 286). The consequences are dire as Lear's metaphorical blindness transforms into a physical one. The recognition scene at the end of the play intertwines Lear's admittance of his denial of Cordelia with his physical recognition of her and acceptance as his daughter. One is the other. This recognition comes too late to save their lives, but not too late to save their humanity.

\section{Recognizing Oneself As Having Wronged the Other}

This very question of how I will take the fact of my own mistake being pointed out to me is the very question Ricoeur discusses under the heading of imputability, which he places at the very summit of human capacities: "with imputability, the notion of a capable subject reaches its highest meaning" (Ricoeur 2007, p. 106). But what is it to impute acts to oneself? Or rather, how is it different from simply ascribing acts to oneself? Ricoeur explains that imputability adds to ascription the idea of "being able to bear the consequences of one's acts, in particular of those taken as faults, wrongs, in which another is reputed to have been the victim" (Ricoeur 2007, p. 105). It is also to recognize that reparations are called for, including blame and praise, "to compensate for a wrong inflicted on others" (Ricoeur 2007, p. 105). Recognizing and acknowledging oneself as having wronged another, as having denied him recognition, as having rejected his testimony, becomes the key to 
one's identity in both Cavellian and Ricoeurian philosophy. The acknowledgment of the denial - and the willingness to bear the consequences - becomes the first step of the reparations, the necessary condition for the true recognition of that other.

That true recognition is where ipseité hides, that is the double bond of recognition we have already discussed. As Ricoeur points out, ipseity can only disappear if ethical identity disappears, "in the sense of a capacity to hold oneself accountable for one's acts" (2007, p. 103). Here it is the acts that connect us with others that come to the foreground. Cavell sees this need to acknowledge the other as an irreducible fact of our condition: the other's life, expressed in his words, "calls upon me; it calls me out. I have to acknowledge it. I am as fated to that as I am to my body" (Cavell 1999, p. 84; This, of course, is a very Levinasian theme, but Cavell, as always, stresses speech as the place where we answer the call of the other). And elsewhere: "our acceptance of the speech of the other is an irreducible fact in our relation to the other" (Cavell 2006, p. 152). That irreducibility also appears in Ricoeur's characterizations of attestation as the belief-in, as opposed to the belief-that: "it is in the speech of the one giving testimony that one believes" (1995, p. 21). And thus our denial of the speech of the other is one of the most basic wrongs. And yet this wrong done to the other, called 'misrecognition' by Ricoeur and 'denial' by Cavell, is inherent in recognition itself, perhaps even providing the initial impulse in the search for selfhood.

As Ricoeur notes, imputability as constitutive of personhood was already postulated by Kant. But Ricoeur is careful not to understand imputability in the purely juridical, Kantian meaning related to law and punishment. That is why he adds the idea of responsibility, and with it, the suffering of the victim: "it is toward this suffering that the idea of responsibility reorients that of imputability" (Ricoeur 2007, p. 108). And with it, on the moral plane, the idea of "vulnerable others" comes to the foreground - they are the object of our responsibility, our "assigned charge", something we are fated to, as Cavell would say. At the same time, Ricoeur postulates against the late Levinasian idea of unlimited responsibility, as it would "amount to indifference, by overthrowing the 'mineness' of my action" (Ricoeur 2007, p. 109). A just measure must be found between the denial and the inflation of responsibility.

Thus the crucial role of conversation as a form of "the test of confronting others" which my narrative must undergo. Cavell writes that we need conversation precisely because the extent of our responsibilities is unclear to us: "Discussion is necessary because our responsibilities, the extensions of our cares and commitments, and the implications of our conduct, are not obvious; because the self is not obvious to the self" (Cavell 1999, p. 312). Further, conversation can lead to my recognition of my misrecognition, to an admittance after some hesitation, to an acknowledgment 
of my own limitedness. To enter into such conversation is a moral act; it requires courage, and it is what is required of a good life. The fullness of identity that we strive for requires a subject willing to accept and come to terms with its errors. So we can ask with Levinas: Am I willing to have another as my teacher? Or with Habermas: Am I willing to admit that the other is a rational being like myself? Or simply with Ricoeur: Am I willing to place myself "under the tutelage of a relationship of reciprocity" (Ricoeur 2007, p. 248)?

\section{Conclusions}

Let us summarize our findings: how does The Course of Recognition square with Ricoeur's philosophy of selfhood, and, more broadly, with philosophy of selfhood in general? How do the concepts of Ricoeurian recognition and Cavellian acknowledgement enrich that philosophy? First of all, at the level of Ricoeur's philosophy of the self, the theme of recognition has revealed itself as a vital step that develops and goes beyond the themes of Oneself as Another. If The Course of Recognition is indeed to be taken as an 'existential elucidation' of selfhood, then the 'authoring of oneself' becomes a broader undertaking, requiring the self to proceed through all the outlined steps of recognition, including, crucially, the possibility of error, of misrecognition of oneself by others, and of wrong done to another. In other words, one could argue that The Course of Recognition proposes a selfhood that is constituted by following that very course, from identification to confrontation with others. Ricoeur's stress on the double bond of recognition, i.e., the intertwining need to recognize and to be recognized, if not a groundbreaking finding, should at least refocus the conversation: if the self is a task, it is a task preformed in the world, the life world, and so the ultimately social, dialogical nature of human beings must be taken into account. Narrative identity must bear the test of dialogue.

Moving beyond interpretations of Ricoeur, we have shown that the themes he points to: recognition, narrative identity as tested by confrontation with others, misrecognition, and dialogue are all poignantly present in the philosophy of Stanley Cavell. His concept of acknowledgment enriches our understanding of recognition and brings several aspects into sharp focus. First, its requirement of expression, i.e. the fact that recognition must be verbalized, the idea of words owed to another, highlights the inherently dialogical aspect of selfhood, as well as the vital role of speech as such in its development. Second, Cavell places acknowledgment in a certain opposition to knowledge, making it an act of judging our state of knowledge, mostly, of admitting our limitedness in this respect. Acknowledgment, we could say, is constantly aware of the possibility of misrecognition. Third, Cavell's presentation of acknowledgment clarifies the stakes: the risks, costs, and difficulties. Lack of acknowledgment is a denial; it is present in everyday gestures, but it can cut so deep that life and death cease to matter. Life is not 
always as 'humanly needful' as the acknowledgment of our identity is. And forth, it implies that our acknowledgement of having wronged another might be the key to our identity. Overall, Cavell, much of whose philosophy investigates "the extent to which my relation to myself is figured in my relation to my words" (Cavell 2002, xxiii), shows that the requirement of outwardness, of intersubjectivity, is what makes acknowledgment crucial for theories of selfhood.

Lastly, there is one more thing that the Cavellian literary examples do for us: they hit home. They show these themes to be not just of philosophical, academic concern, but of human concern, of everyday concern for us. They call philosophy to yet again answer the question of how to live. Perhaps reading Cavell and Ricoeur together can put back the sense of urgency into our philosophical investigations.

\section{References}

Cavell, S. 2003. Disowning Knowledge in Seven Plays of Shakespeare. New York: Cambridge University Press.

Cavell, S. 1994. In Quest of the Ordinary. Lines of Skepticism and Romanticism. Chicago: The University of Chicago Press.

Cavell, S. 2002. Must We Mean What We Say? Cambridge: Cambridge University Press.

Cavell, S. 2006. Philosophy the Day after Tomorrow. Cambridge, MA: The Belknap Press of Harvard University Press.

Cavell, S. 1999. The Claim of Reason: Wittgenstein, Skepticism, Morality, and Tragedy. New York: Oxford University Press.

Ricoeur, P. 1995. Oneself as Another. Trans. K. Blamey. Chicago: The University of Chicago Press.

Ricoeur, P. 2007. The Course of Recognition. Trans. D. Pellauer. Cambridge, MA: Harvard University Press. 
Klementyna Chrzanowska

(Jagiellonian University in Cracow, cklementyna@gazeta.pl)

\title{
Searching for Selfhood: Ricoeur's Recognition and Cavellian Acknowledgment
}

\begin{abstract}
Ricoeur's theory of narrative identity is not his last word when it comes to philosophy of selfhood. This paper aims to outline how the findings of one of Ricoeur's final books, The Course of Recognition fit into Ricoeur's philosophy of selfhood, and to do so by comparing Ricoeur's analyses of the concept of recognition and Stanley Cavell's explorations of the idea of acknowledgment. Cavell, much of whose philosophy investigates "the extent to which my relation to myself is figured in my relation to my words," can show recognition to be not only the gaining of knowledge, but the outward affirmation, acceptance, agreement to that knowledge (in language). That requirement of outwardness, of intersubjectivity, is what makes acknowledgment crucial for theories of selfhood.
\end{abstract}

Keywords: Paul Ricoeur, Stanley Cavell, acknowledgment, recognition, intersubjectivity, selfhood

Ethics in Progress (ISSN 2084-9257). Vol. 7 (2016). No. 1, Art. \#14, pp. 199-213.

doi: 10.14746/eip.2016.1.12 